\title{
Plasmodium Vivax-Precipitated Neurological Symptoms: Central Nervous System Idiopathic Inflammatory Demyelinating Disease/Multiple Sclerosis
}

\author{
Ahmet Kasım Kılıç, Öznur Ak, ${ }^{2}$ Muhammed Yakın, ${ }^{2}$ Yasemin Nadir, ${ }^{2}$ Serdar Özer ${ }^{2}$
}

\author{
'Department of Neurology, Kartal \\ Dr. Lütfi Kırdar Training and \\ Research Hospital, Istanbul, Turkey \\ ${ }^{2}$ Department of Infectious Diseases \\ and Clinical Microbiology, \\ Kartal Dr. Lütfi Kırdar Training and \\ Research Hospital, İstanbul, Turkey \\ Submitted: 27.08 .2016 \\ Accepted: 04.12.2017 \\ Correspondence: Ahmet Kasım Kılıç, \\ Kartal Dr. Lütfi Kırdar Eğitim ve \\ Araştırma Hastanesi, Nöroloji \\ Kliniği, İstanbul, Turkey \\ E-mail: kasimkilic@yahoo.com

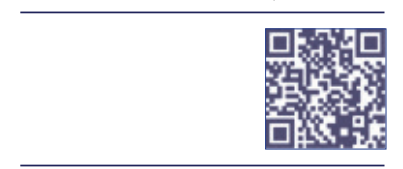 \\ Keywords: Clinical isolated \\ syndrome; malaria; multiple \\ sclerosis; plasmodium.
}

\begin{abstract}
Clinically isolated syndrome (CIS) and multiple sclerosis are autoimmune diseases of the central nervous system that are characterized by inflammation, demyelination, and axonal damage. Clinical symptoms can be aggravated by fever or concomitant infection. Malaria can also demonstrate neurological symptoms and develop into cerebral malaria, which can lead to severe neurological disability. The present patient had a diagnosis of Plasmodium vivax infection and displayed neurological symptoms and fever. After exclusion of cerebral malaria and other infectious diseases, the patient had a final diagnosis of CIS and the appropriate treatment was initiated. This report is a description of this rare presentation.
\end{abstract}

\section{INTRODUCTION}

Clinically isolated syndrome (CIS), acute disseminated encephalomyelitis (ADEM), and multiple sclerosis (MS) are included in the spectrum of idiopathic inflammatory demyelinating diseases of the central nervous system, and these autoimmune diseases are characterized by inflammation, demyelination, and axonal damage. ${ }^{[1,2]}$ Clinical symptoms may be precipitated or worsened by fever or concomitant infection. ${ }^{[3]}$ Malaria is also an important infectious disease that may course with neurological signs, and may induce cerebral malaria syndrome, potentially causing neurological disability. In 2015, 238 million cases, which led to 438,000 deaths, were reported. ${ }^{[4]}$ Plasmodium falciparum is the causative agent in $94 \%$ of cases. ${ }^{[4]}$ Plasmodium vivax infection can also manifest with signs of cerebral malaria. ${ }^{[5]}$ Described is a case of Plasmodium vivax infection with an onset of atypical neurological symptoms and radiological signs of a central nervous system demyelinating disease.

\section{CASE REPORT}

A 33-year-old male patient presented at the emergency service with complaints of fever and difficulty walking due to instability in the left lower extremity. His initial examination findings were unremarkable and he was discharged. Following re-emergence of fever approximately I week later, he was admitted to the ward of infectious diseases for investigation. His personal medical history was uneventful. It was learned that his neurological complaints 
started with the onset of fever. He had no neurological complaints during afebrile periods; however, during repeated febrile attacks, similar symptoms recurred. A detailed anamnesis revealed that he had gone to Nigeria for work without prophylactic treatment for malaria. His fever manifested on the day of his return from Nigeria. Neurological examination results on admission were within normal limits without any findings of encephalopathy, stiff neck, or meningeal irritation. His chart demonstrated that his fever increased to $38.9^{\circ} \mathrm{C}$ and $40^{\circ} \mathrm{C}$. Parasites were not seen in microscopic examination of thin and thick smears. Rapid antigen test result was negative. The biochemical test results were as follows: whole blood count: 4400/ $\mathrm{mm}^{3}$, polymorphonuclear leukocytes: $86 \%$, hemoglobin: $14.2 \mathrm{~g} / \mathrm{dL}$, hematocrit: $43 \%$, platelet count: $13000 / \mathrm{mm}^{3}$, Creactive protein: $179 \mathrm{mg} / \mathrm{L}$ (normal range: $0-5 \mathrm{mg} / \mathrm{L}$ ), procalcitonin: $0.4 \mathrm{ng} / \mathrm{mL}$, and erythrocyte sedimentation rate: $20 \mathrm{~mm} /$ hour. Excluding alanine transaminase (62 U/L), his biochemical values were within normal limits. An abdominal ultrasound demonstrated only a mild degree of hepatomegaly. A neurological examination during a febrile attack with a body temperature of $39.2^{\circ} \mathrm{C}$ revealed the presence of horizontal nystagmus and ataxia. The patient was also vomiting. Contrast-enhanced cranial magnetic resonance
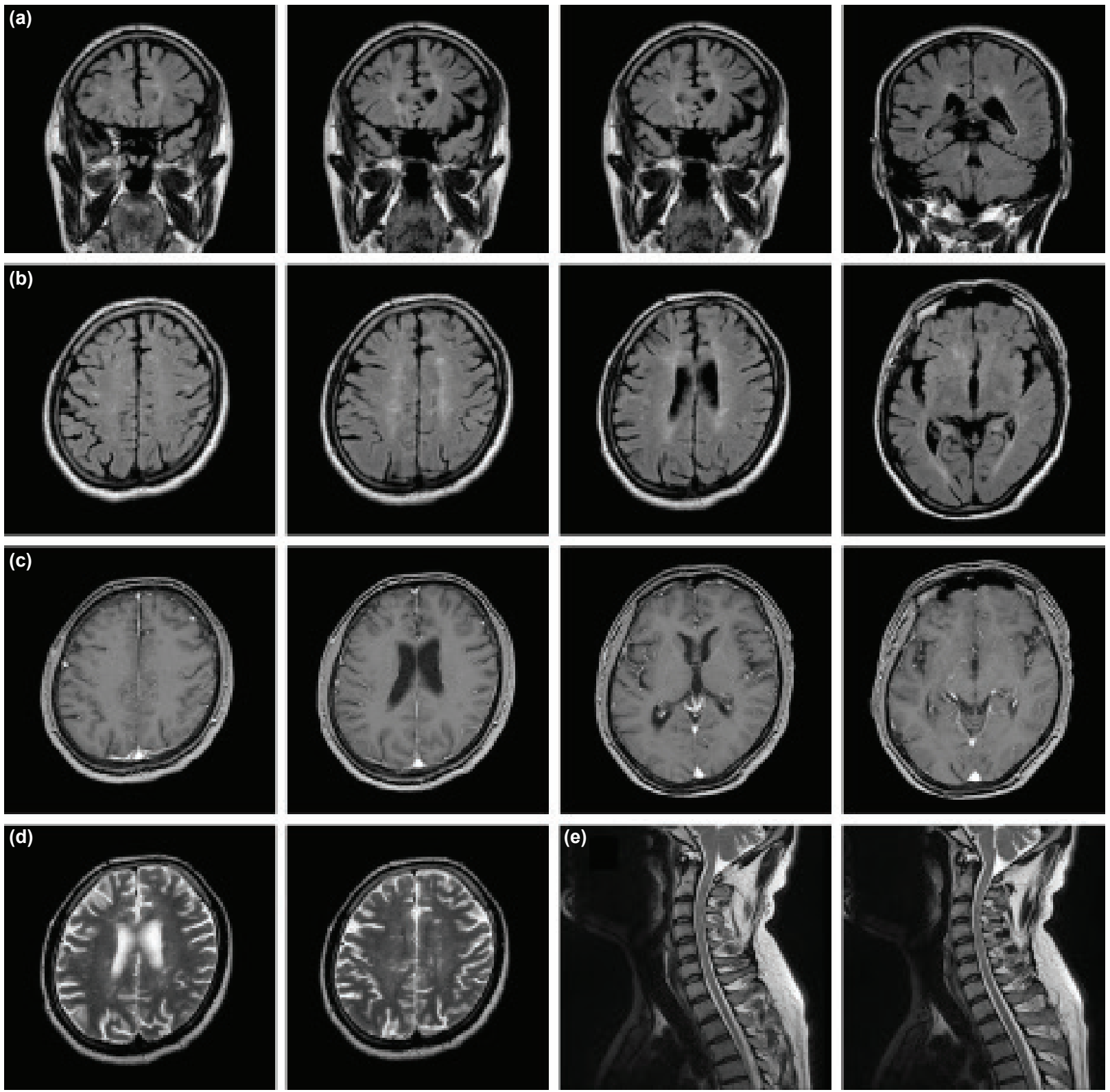

Figure 1. Hyperintensive lesions localized in the periventricular white matter are displayed on (a) coronal and (b) axial FLAIR sections. Some of these periventricular lesions were situated perpendicular to the ventricle, which supported the presence of perivenular inflammation (a, b, d). As seen in T1-weighted contrast images (c), none of the lesions had gadolinium uptake. (e) In T2-weighted spinal cord images, hyperintense demyelinating plaques scattered from the cervical to the thoracic vertebrae can be seen. 
imaging (MRI) demonstrated T2-weighted hyperintense lesions localized in the supratentorial white matter, some of which were perpendicular to the ventricle, suggesting perivenular inflammation (Fig. I). The lesions did not demonstrate contrast material uptake. Non-contrasted, scattered, hyperintense lesions were detected on T2-weighted cervical and thoracic MRI (Fig. I). Though the appearance of the lesions on MRI was consistent with central nervous system demyelinating disease, tests were performed for lesions that can mimic these diseases, including syphilis, Lyme disease (Borrelia burgdorferi lgG/M), HIV, and Brucella (Rose Bengal, Wright agglutination tests) which all yielded negative results. Biomarkers of vasculitis were not detected. Analysis of cerebrospinal fluid (CSF) sample obtained through lumbar puncture revealed CSF protein of $50 \mathrm{mg} / \mathrm{dL}$ and CSF glucose of $55 \mathrm{mg} / \mathrm{dL}$ (simultaneous blood glucose: $98 \mathrm{mg} / \mathrm{dL}$ ). CSF smear was acellular. Herpes simplex polymerase chain reaction test was negative, and acid-fast bacilli were not detected in the CSF. The presence of CSF type 2 oligoclonal bands was observed, and lgG index was within normal limits.

During follow-up in the ward, the patient had another febrile episode, so thin and thick smear samples were prepared again. Plasmodium trophozoites and schizonts were observed in abnormally large and faintly colored red blood cells on Giemsa dye-stained smears. The national Center for the Fight Against Malaria was contacted and the parasite was identified as Plasmodium vivax. Antimalarial treatment was initiated with artemether/lumefantrin, followed by primaquin treatment for 14 days. A control MRI obtained following treatment of the infection indicated that the lesions were stable. The World Health Organization has described cerebral malaria as a comatose state persisting for at least for I hour after a convulsive episode or after resolution of hypoglycemia that cannot be explained by any other etiology, together with the presence of Plasmodium falciparum in peripheral blood samples. ${ }^{[6]}$

It was thought that the clinical symptoms manifested were more consistent with false attacks provoked by fever, and the appearance of the lesions suggested central nervous system inflammatory demyelinating disease rather than cerebral malaria. During a follow-up period lasting nearly a year, neurological progression was observed and the diagnosis of MS was made. As the patient had an active professional life and clinical follow-up demonstrated a progressive course, glatiramer acetate treatment was initiated.

\section{DISCUSSION}

Malaria is still one of the leading causes of death and neurological disability in tropical countries, and $40 \%$ of the world population is at risk. ${ }^{[7]}$ Cerebral malaria is a comatose state with sudden onset of seizures, and it has been associated with the emergence of postmalarial metabolic and inflammatory mediators. ${ }^{[7]}$ When the available data were considered, our case was not consistent with the definition of cerebral malaria. ${ }^{[6]}$ However, a similar case of demyelinating disease with a diagnosis of ADEM following a malarial infection (Plasmodium falciparum and vivax) was reported in India. ${ }^{[8]}$ Studies performed in Sardinia investigated a genetic association between malaria and MS; an increase in the incidence of MS was observed following eradication of malaria in Sardinia. ${ }^{[9]}$ In another study performed in Sardinia, the frequency of tumor necrosis factor alleles $238 \mathrm{~A}$ and $376 \mathrm{~A}$ was greater in the control group as well as in stroke and MS patients. ${ }^{[10]}$ Although malaria was eradicated in Sardinia, peripheral mononuclear cells of MS patients demonstrated an increased proliferation capacity, cytokine release, and the ability to kill the Plasmodium falciparum parasite. ${ }^{\left[{ }^{[I]}\right.}$ It was also determined that these cells carried a TNF-376A polymorphism and the class II HLA-DRB*0405 allele, and demonstrated a genetic predisposition. ${ }^{[I]}$ Macrophage hyperactivity has been shown in regions of endemic malaria. However in Sardinia, the presence of increased macrophage activity despite eradication of malaria was seen in greater plasma chitotriosidase (CHIT) activity and decreased allelic frequency of the CHITI gene mutation known to be related to increased prevalence of MS. ${ }^{[9]}$ The presented case had an onset characterized by radiological images mimicking ADEM and neurological symptoms provoked by fever, and was diagnosed as MS based on progressive neurological findings.

MS, ADEM, and CIS are examples of central nervous system inflammatory demyelinating diseases. ${ }^{[1,2]}$ In demyelinating diseases, neurological findings may be triggered by systemic infections, T-cell activation may increase, and new MRI lesions may occur. ${ }^{[12]}$ Fever or a hot environment may trigger or worsen neurological symptoms in the manner of false attacks. ${ }^{[3]}$ Upper respiratory tract infections and urinary tract infections are also associated with false attacks. $^{[3]}$

This case was presented because of its rarity, atypical onset, clinical progression without malarial activation, and probable genetic/immunological correlates.

\section{Informed Consent}

Approval was obtained from the patient.

Peer-review

Internally peer-reviewed.

Authorship Contributions

Surgical and Medical Practices: Ö.A., M.Y., Y.N., S.Ö., A.K.K.; Concept: A.K.K., Ö.A.; Design: Ö.A., A.K.K.; Data collection \&/or processing: A.K.K.; Analysis and/or interpretation: A.K.K., Ö.A.; Literature search: A.K.K., ÖA; Writing: A.K.K.; Critical review: A.K.K.

Conflict of Interest

None declared. 


\section{REFERENCES}

1. Thouvenot É. Update on clinically isolated syndrome. Presse Med 2015;44:e121-36. [CrossRef]

2. Popescu BF, Pirko I, Lucchinetti CF. Pathology of multiple sclerosis: where do we stand? Continuum (Minneap Minn) 2013;19:901-21.

3. Thrower BW. Relapse management in multiple sclerosis. Neurologist 2009;15:1-5. [CrossRef]

4. WHO. World Malaria Report 2015. Geneva: World Health Organization; 2015. p. 280.

5. Manning L, Laman M, Law I, Bona C, Aipit S, Teine D, et al. Features and prognosis of severe malaria caused by Plasmodium falciparum, Plasmodium vivax and mixed Plasmodium species in Papua New Guinean children. PLoS One 2011;6:e29203. [CrossRef]

6. Severe falciparum malaria. World Health Organization, Communicable Diseases Cluster. Trans R Soc Trop Med Hyg 2000;94 Suppl $1: \mathrm{S} 1-90$.
7. Idro R, Marsh K, John CC, Newton CR. Cerebral malaria: mechanisms of brain injury and strategies for improved neurocognitive outcome. Pediatr Res 2010;68:267-74. [CrossRef]

8. Mani S, Mondal SS, Guha G, Gangopadhyay S, Pani A, Das Baksi $S$, et al. Acute disseminated encephalomyelitis after mixed malaria infection (Plasmodium falciparum and Plasmodium vivax) with MRI closely simulating multiple sclerosis. Neurologist 2011;17:276-8.

9. Sotgiu S, Angius A, Embry A, Rosati G, Musumeci S. Hygiene hypothesis: innate immunity, malaria and multiple sclerosis. Med $\mathrm{Hy}$ potheses 2008;70:819-25. [CrossRef]

10. Wirz SA, Morale MC, Marchetti B, Barr AM, Sotgiu S, Rosati G, et al. High frequency of TNF alleles $-238 \mathrm{~A}$ and $-376 \mathrm{~A}$ in individuals from northern Sardinia. Cytokine 2004;26:149-54. [CrossRef]

11. Sotgiu S, Sannella AR, Conti B, Arru G, Fois ML, Sanna A, et al. Multiple sclerosis and anti-Plasmodium falciparum innate immune response. J Neuroimmunol 2007;185:201-7. [CrossRef]

12. Correale J, Fiol M, Gilmore W. The risk of relapses in multiple sclerosis during systemic infections. Neurology 2006;67:652-9. [CrossRef]

\section{Plazmodium Vivax’ın Tetiklediği Nörolojik Bulgular: Santral Sinir Sistemi İdyopatik Enflamatuvar Demiyelinizan Hastalığı/Multipl Skleroz}

Multipl skleroz veya klinik izole sendrom santral sinir sisteminin otoimmün bir hastalık spekturumunda olup enflamasyon, demiyelinizasyon ve aksonal hasarla seyretmektedir. Nörolojik bulgular bazen bir enfeksiyon sırasında veya ateş ile agreve olabilmektedir. Ayrıca malarya da nörolojik bulgularla birlikte serebral malarya sendromunu oluşturabilmekte ve nörolojik özüre neden olabilmektedir. Sunulan olguda da Plazmodium vivax enfeksiyonu sırasında ateşle ortaya çıkan nörolojik bulguların değerlendirilmesi sonucu serebral malaryoz ve diğer etkenler dışlanarak hastaya santral sinir sistemi enflamatuvar demiyelinizan hastalığı tanısı konmuş ve tedavisi düzenlenmiş olup nadir görülen bir birliktelik nedeni ile sunulmuştur.

Anahtar Sözcükler: Klinik izole sendrom; malariyazis; multipl skleroz; plasmodium. 